\title{
Nursi's Sufism Without Sufi Order: A Centemporary Debate Among The Ulama
}

\section{Siswoyo Aris Munandar, ${ }^{1}$ Jazilus Sakhok, ${ }^{2}$ Puji Astuti, ${ }^{2}$ Elia Malikhaturrahmah ${ }^{3}$}

\author{
${ }^{1}$ Sekolah Tinggi Filsafat Islam SADRA Jakarta, Indonesia \\ ${ }^{2}$ Sekolah Tinggi Agama Islam Sunan Pandanaran Yogyakarta, Indonesia \\ ${ }^{3}$ Universitas Islam Negeri Sunan Kalijaga Yogyakarta, Indonesia \\ siswoyoaris31@gmail.com
}

\begin{tabular}{c}
\hline Article \\
Information \\
\hline
\end{tabular}

Submitted: January 06, 2020

Revised 1: January 14, 2020

Revised 2: September 02, 2020

Accepted: December 22, 2020

Keywords

Sufism, Sufi Order,

Spiritual

\section{Kata Kunci}

Sufisme, Tarekat, Spiritual

\section{Abstract}

Some scholars think that people who take up religious beliefs are synonymous with being committed, so that many people want to have congregation. However, there are also scholars like Badiuzzaman Said Nursi who think that tasawuf does not have to be committed. The statement of Sufism and tarekat according to Nursi as a way to recognize the nature of faith and the essence of al-Qur'an became a spiritual path under the guidance of the Prophet's sunnah. This article aims to explain the main thoughts of Nursi's Sufism and Nursi's thoughts on tasawuf without any commitment. This research is a research library. The approach used is a socio-historical approach with content analysis techniques. The results showed that Sufism without tarekat, according to Nursi, is someone who has tasawuf does not have to follow the teachings of a tarekat that has a teacher or murshid, only by always reciting the name of Allah, and always carrying out the obligatory commands of Allah and the sunnah, then he will feel close to Allah. This Nursi thought is a new thing that will make it easier for someone to be closer to Allah.

\section{Abstrak}

Pada sebagian ulama beranganggapan bahwa orang yang bertasawuf itu identik dengan bertarekat, sehingga banyak orang yang ingin bertarekat. Walaupun demikian ada pula ulama seperti Badiuzzaman Said Nursi yang berpikiran bahwa bertasawuf tidak harus bertarekat. Pernyataan tasawuf dan tarekat menurut Nursi sebagai jalan untuk mengenal hakikat 
keimanan dan hakikat al-Qur'an menjadi jalan rohani di bawah panduan sunnah Nabi. Artikel ini bertujuan menjelaskan pokok-pokok pemikiran tasawuf Nursi dan pemikiran Nursi tentang bertasawuf tanpa bertarekat. Penelitian ini merupakan penelitian kepustakaan (library research). Pendekatan yang digunakan adalah pendekatan sosio historis dengan teknik analisis isi. Hasil penelitian menunjukkan bahwa tasawuf tanpa tarekat menurut Nursi adalah seseorang yang bertasawuf tidak harus mengikuti ajaran tarekat yang memiliki seorang guru atau mursyid, hanya dengan selalu berzikir mengagungkan nama Allah, dan selalu melaksanakan perintah Allah yang wajib serta sunnah maka ia akan merasakan dekat dengan Allah. Pemikiran Nursi ini merupakan suatu hal baru yang akan memudahkan seseorang untuk lebih dekat kepada Allah.

\section{Introduction}

Sufism is an inner side of Islamic teachings, in addition to being an inner side, sufism also provides a vision of the meaning of life in religion. ${ }^{1}$ In the life of modern society, sufism is needed in guiding people towards the path of peace in the midst of an increasingly arid life and waning the values of spiritualism. It cannot be denied that the existence of sufism for modern society is very much needed, because the human heart has been eroded by a materialistic worldview that is all material. Thus sufism is an alternative for the escape of modern society who wants to sharpen the eyes of the heart towards the path of God. ${ }^{2}$

In general, many scholars believe that sufism is synonymous with fighting, because most of the scholars think that sufis order is important in order to emphasize someone in sufism, because sufism is not just reading sufism literature or mastering sufism only and that has been said a sufi is not, but there must be a process of practice and practice. While between the practitioner and the practice there needs to be a guiding guide, so here a student is needed and a binding in the world of the sufi order. Like a cleric that is, Luqman Hakim

${ }^{1}$ Edy Yusuf Nur, Menggali Tasawuf Yang Haqiqi (Yogyakarta: SUKA-Pres UIN Sunan Kalijaga, 2014), 175.

${ }^{2}$ Samsul Munir Amin, Ilmu Tasawuf (Jakarta: AMZAH, 2012), 57. who argues that a person who is sufism without following the sufi order is equal to zero. So many people want to enter the institute.

Sufism is basically the process of going to Allah by purifying oneself and also having faith in Allah. While sufis order is one of the ways in which someone who wants to draw closer to Allah. ${ }^{3}$ Therefore, sufism is not the same as fighting, because sufism is more about the process of purification of the heart that sometimes wants to be obtained by people who want to be close to God. The reality was not like that, there were some opinions of the scholars who thought that the sufis order was not something that was required or required to be taken by someone.

The Naqshbandiyah sufi order is the closest order to the life of Nursi. ${ }^{4}$ However, although Said Nursi grew up in the Naqshbandiyah sufi order but never joined the sufi order or followed the path of the sufi order, ${ }^{5}$ even Nursi always said that "This century is not a century of orders. But this century

\footnotetext{
${ }^{3}$ Badiuzzaman Said Nursi, Al-Maktûbât, translated by Fauzi Faisal Bahreisy, 1st edition (Banten: Risalah Nur Press, 2017), 765; Akhmad Rizqon Khamami, "Kontribusi Gerakan Nurcu dalam Kebangkitan Islam di Turki," Islamica: Jurnal Studi Keislaman 10, no. 1 (2015).

${ }^{4}$ Muhammad Faiz, "Risalah Nur dan Gerakan Tarekat di Turki: Peran Said Pada Awal Pemerintahan Republik," Al-A'raf XIV, no. 1 (2017): 38.

${ }^{5}$ Sukran Vahide, Biografi Intelektual Bediuzzaman Said Nursi: Trasformasi Dinasti Usmani Menjadi Republik Turki (Jakarta: Fajar Interpratama Offset, 2007), 6.
} 
is a century of saving the faith." ${ }^{\prime 6}$ Something very valuable from Nursi's thoughts is his association with sufism. Nursi who has been fostered from an early age with sufi life so that there is no doubt that sufism is very coloring and the most prominent of the thoughts and works that it produces. Sufi so that there is no doubt that sufism is very coloring and the most prominent of the thoughts and works that it produces. ${ }^{7}$

The interesting thing from Badiuzzaman is that he has built sufi traditions that are different from sufism style in general which usually builds the context of sufism by having to follow a sufi order institution, here Nursi wants to build a context of purifying the heart using sufism by practicing the sufi order in the context of his teachings without any a murshid. Therefore Nursi tried to turn exclusive sufism that is closed only certain people who can sufism, become inclusive sufism that is open to all people can do sufism without having to fight, by building all paths of sufism based on the Qur'an. Therefore Nursi built sufism which is called by nature and not sufi order. ${ }^{8}$ According to Badiuzzaman's observations, a fundamental problem for the majority of Muslims, especially Muslims in Turkey in the $20^{\text {th }}$ century, was to save their faith and strengthen their faith which was increasingly hit by the crisis because it was hit by the onslaught of secularism and materialism. ${ }^{9}$

Therefore, Nursi tried to interpret the teachings of sufism by directly drawing lanterns of wisdom from the Qur'an and the Sunnah of the Prophet as two fundamental sources of Islam. ${ }^{10}$ Not only that Nursi also provides a new modern understanding that is by making sufism as a purification of the heart that can be done by anyone who wants to

\footnotetext{
${ }^{6}$ Thsan Kasim Salih, Said Nursi: Pemikiran Dan Sufi Besar Abad 20 Membebaskan Agama dari Dogmatisme \& Sekularisme (Jakarta: PT. Raja Grafindo Persada, 2003), 188.

${ }^{7}$ Suhayib, "Pemikiran Said Nursi dalam Pemberdayaan Politik (al-Tamkin al-Siyasi) Masyarakat Muslim Turki (Studi atas Kitab al-Matsnawi an-Nuri)," An-Nida' 38, no. 1 (2013): 65. ${ }^{8}$ Ibid.

${ }^{9}$ Zaprulkhan, Ilmu Tasawuf: Sebuah Kajian Tematik (Jakarta: Rajawali Pers, 2016), 210.

${ }^{10}$ Ibid.
}

really draw closer to God, without the need for a student who in the sense does not have to enter an institution sufi order. For this reason Nursi thoughts are very interesting if examined more deeply, bearing in mind that there are still many perceptions that identify sufism with sufi order in the Muslim community. According to the writer, sufism without sufi order is an interesting phenomenon to be studied, and tickled the writer to explore it further.

This research is a library research. The data collection technique used is documentation, which is by looking for evidence from non-human sources related to the object under study, in the form of writings, pictures, monumental works of a person such as reading and taking from books and related literature. After that, the text data analysis from primary and secondary data was carried out (using content analysis) related to Nursi's Sufism thoughts.

Based on the background of the problems mentioned above, the objectives of this study are: First, to find out the main points of sufism from Badiuzzaman Said Nursi. Second, to find out the thoughts of Badiuzzaman Said Nursi regarding sufism but do not fight.

\section{The Meaning and Understanding of Sufism}

Sufism is a manifestation taken by believers through a process of effort in order to tie the Shari'a through the sufi order to achieve makrifat. ${ }^{11} \mathrm{Al}-\mathrm{Izz}$ ibn Abdussalam mentions that Sufis are among those referred to in the word of God as Hezbullah or equal to the party of Allah, in Surah al-Maidah (5):56, and al-Mujadilah (58):22, according to this definition sufism is the improvement of the heart, where if the heart is healthy, then the person will look healthy too, but if the heart hurts then that person will look sick too. He considers that the knowledge of the rule of law was born as an understanding of law in general, while the knowledge of the problem

\footnotetext{
${ }^{11}$ Jamaluddin Kafie, Tasawuf Kontemporer (Jakarta: Republika, 2003), 8.
} 
of mysticism as a soft understanding of detailed law. ${ }^{12}$

Sufism is a science that is different from other Islamic sciences because its explanation or understanding is the most difficult thing. This is because sufism is a science that is closely related to a spiritual experience and because its inner nature is individual or subjective, not all sufis experience the same. Therefore, the meaning, definition or understanding they make is different from each other. Maybe this is the only science that is subjective and can only be understood by people who have had spiritual experience at a similar level. Sufis make the definition of sufism by following what they have experienced and felt in their soul or mind when they are in a situation that is directly related to Allah. ${ }^{13}$ However, not all definitions or meanings that they make describe the nature or content of the experience because there are also definitions that are the path to God. The definition in this case, is the character of sufism that can not be separated from sufism itself. Because, sufism in Islam is not only limited to the environment of an inner experience with God but also all legal waysthat can bring people to God. ${ }^{14}$

Sufism is also a branch of Islamic science that emphasizes the dimensions or spiritual aspects of Islam. This spirituality can take various forms in it. Relation to humans, sufism emphasizes more spiritual aspects than physical aspects. In relation to life, he places more emphasis on the afterlife rather than the life of the mortal world. While its relation in religious understanding, sufism emphasizes more inward interpretation than in outward interpretation. ${ }^{15}$

\footnotetext{
${ }^{12}$ Syekh Muhammad Hisyam Kabbani, Tasawuf dan Ihsan (Antivirus Kebatilan dan Kezaliman) (Jakarta: Serambi Ilmu Semesta, 2007), 186

${ }^{13}$ Jazilus Sakhok and Siswoyo Aris Munandar, "The Sufi Order and Phianthropy: A Case Study of Philantrophical Activitism of The Naqsyabandiyah Al-Haqqani Sufi Order in Indonesia," Teosofia: Indonesia Journal Of Islamic Mysticism 8, no. 1 (2019): 32.

${ }^{14}$ Ahmad Daudy, Kuliah Ilmu Tasawuf (Jakarta: Bulan Bintang, 1998), 21.

${ }^{15}$ Mulyadhi Kartanegara, Menyelami Lubuk Tasawuf (Jakarta: Erlangga, 2006), 2.
}

Besides that, sufism is also very concerned about the aspects of the heart and soul. However, sufism also does not rule out aspects of physical worship and also property. Sufism itself has also formulated a practical method that can lead a Muslim to the level of perfection of faith and morals. Sufism is not only in the form of reading wirid, dhikr and remembrance, as is considered by some circles so far. There is something missing from the minds of many people, namely that sufism is a practical and perfect method that can change a person from a distorted personality to a straight, ideal and perfect personality. The change covers aspects of searching for faith, worship, and also sincerity, good mu'amalah and good character. This is a function and benefits of sufism for us. ${ }^{16}$

According to Nursi's own opinion, the definition of sufism is a way to recognize the nature of the faith and nature of the Qur'an through the spiritual path under the guidance of the Prophet Muhammad's sunnah, which starts from the step of the heart so as to achieve a sense of zauq that draws closer to the level of witnessing the shuhūd to Allah swt. The definition of sufism explained by Nursi emphasizes the object and target of sufism itself, namely the attainment of the nature of faith and the revelation of the nature of the Qur'an as the basis and guide of human life. Besides that, it can also be understood that the sunnah of the Prophet Saw is a guideline that guides a person's sufi path to the level of closeness to Allah, known in the environment of sufism with the term makrifatullah. ${ }^{17}$

Thus of all the opinions of the scholars on the understanding of sufism above, sufism can be interpreted simply by means of a system of training with the sincerity of riyadah to cleanse,

\footnotetext{
${ }^{16}$ Syaikh 'Abdul Qodir Isa, Hakekat Tasawuf (Jakarta: Qisthi Press, 2005), 18.

${ }^{17}$ Sulaiman al-Kumayi, "Konsep Sufisme 'Shakhs-I Manevi dan Hizmet Muhammad Fathullah Gulen," Jurnal Studi Keislaman 17, no. 2 (2013): 370; Farikhatul Lathifah, "Pemikiran Taqarrub Badiuzzaman Said Nursi (Studi Analisis Kitab Risalah AnNur)", 71 .
} 
enhance and also deepen spirituality in order to draw closer to Allah Almighty, so that one's concentration is only directed towards Allah Almighty course and sufism also teaches how the behavior of the Prophets and Apostles. Teachings about worship, muamalah and morals as a jewel for the Prophets and Apostles. So in essence, sufism is indeed based on a life that is fully filled with total unity of Allah and love of the Prophet. This must be accompanied by sincerity, patience and also gratitude for all his destiny and life and the way to achieve this path must be balanced with good character.

\section{Thought Sufism Without Sufis Order Badiuzzaman Said Nursi and Response Of Ulama}

\section{a. According to Nursi Sufi Orders in Sufism}

A historian of sufism J. Spencer Trimingham, stated that the sufi order was originally a gradual method of contemplative and self-purification. A group of students gathered around a prominent sufi teacher, together to undertake spiritual training but were totally unrelated in any form of allegiance. He called this first period sufi order as an expression of pure personal diversity that was at odds with the institutionalization of religion based on human autonomy. In the second period, around the twelfth century, spiritual training then institutionalized on the basis of the teacher's lineage and the oath of allegiance. As a result, in the third period, around the fifteenth century, the sufi order changed into a hierarchical organizational structure. According to Trimingham, ${ }^{18}$ the sufi order can be understood in two senses, firstly, the sufi order in the sense of a spiritual path to Allah, and this is the sufistic method of drawing closer to God. Secondly, the sufi order in the sense of holy brotherhood where there is a gathering of a number of students and a teacher, assisted by the murshid the other. ${ }^{19}$ Nursi in this case took the understanding of the first

\footnotetext{
${ }^{18}$ Haidar Bagir, Buku Saku Tasawuf Positif (Bandung: Mizan Pustaka, 2005), 178.

${ }^{19}$ Mulyadhi Kartanegara, Menyelami Lubuk Tasawuf, 37.
}

sufi order which is the spiritual path through the Sufistic method in getting closer to Allah.

Sufi orders means the way. Meanwhile, according to the term sufism, sufi order means the journey of a salik or sufi order follower to Allah by purifying oneself or the journey that must be taken by someone to be as close to God as possible. Meanwhile, according to Ali al-Jurjani, the sufi orders is a special method used by the salik or the wayfarers of the sufi order towards Allah by going through stages or maqomat. The term sufi order is sometimes used to refer to a personal guidance and behavior carried out by a murshid to his students. This understanding is usually understood by many people. From here the sufi order has two meanings. First, as a method of giving spiritual guidance to individuals in directing their lives towards closeness to God. Second, the order of the sufi brotherhood marked by the existence of formal institutions such as zawiyah, rubath, or khanaqah. ${ }^{20}$

Besides that the sufi order is also a path taken by sufis and is described as a path that originates from the Shari'a, because the main road is called syari ', while the child walk is called tharìq. This derivative word shows that in the opinion of the sufis, mystic education is a branch of the main road consisting of divine law, which is a foothold for every Muslim. There is no way for a child to walk without a main road where he starts. Mystical experience is not possible if the binding orders of the Shari' ah are not obeyed in advance. ${ }^{21}$

According to Nursi there are two kinds of sufi order namely the obligatory sufi order and the sunnah sufi order. Mandatory orders, which are mandatory practices, both fard $u$ 'ain and fard $u$ kifayah which must be carried out by each Muslim. ${ }^{22}$ The main mandatory sufi order is to

\footnotetext{
${ }^{20}$ Aziz Masyhuri, Ensiklopedi 22 Aliran Tarekat dalam Tasawuf (Surabaya: IMTIYAZ, 2011), 2.

${ }^{21}$ Muh. Gitosaroso, Syari'at dan Tarekat dalam Persepektif Jama'ah (Studi atas Jama'ah Tarekat Haq Naqsabandiyah di Kota Pontianak), (Pontianak: IAIN Pontianak Press, 2017), 25.

${ }^{22} \mathrm{http}: / /$ www.sarjanaku.com/2011/11/person-tarekat-andsejarah.html, accessed on August 18, 2019, at 12:19
} 
practice the pillars of Islam. Obligatory practices will make his practice a pious person maintained by God. This mandatory order has been determined by Allah through the Qur'an and al-Hadith. Examples of the main mandatory practices are prayer, fasting, almsgiving, pilgrimage. Other mandatory practices include closing genitals, halal foods and so forth. The Sunnah sufi order is a collection of practices of circumcision and mubah which are directed according to the five conditions of worship to make their practitioners become pious people. People who practice the Sunnah sufi order must have practiced the obligatory sufi order. So the Sunnah sufi order is an addition to the obligatory sufi order. This Sunnah sufi order was composed by a murshid teacher to be practiced by students and followers. The contents of the Sunnah sufi order are not fixed, and depend on the circumstances of the sufi order era and also the condition of the student or follower. The things that can be the contents of the Sunnah sufi order are circumcision prayer, reading the Qur'an, circumcision fasting, wirid, remembrance and so forth.

Nursi also emphasized that para sufis attest to the divine mission and the order witnessing the Shari'a. They also illustrate the perfection of Islam, according to him the most beautiful and upright or righteousness is the one that coincides with the sunnah and the most firmly adheres to Islamic law, the main principle is sincerity, when in recognizing God with love for God is the most important step. All paths according to Nursi's view are to achieve the truth of the Shari'a and all the results are included in the ratification of Shari'a. Sufi practice is a scientific discipline that enables humans to observe the Shari'a in the best possible way and follow the Sunnah as a principle. ${ }^{23}$

\footnotetext{
${ }^{23}$ Syed Hadzrullathfi Syed Omar \& Nurul Aarifah Musa, "Tarekat Sufi Suatu Keperluan Zaman: Sorotan Pandangan Badiuzzaman Said Al-Nursi", Proceedings of ICIC 2015 - International Conference on Empowering Islamic Civilization in the 21st Century. 6-7 September 2015, Terengganu, Malaysia, 413.
}

Nursi explained that someone who will draw closer to Allah by always making remembrance and glorifying the name of Allah is none other than by carrying out the commands of Allah that is by taking the path of Shari'a, essence and order. What is meant by sufi order here is a sufi order that follows the sunnah not through the association between the murshid and the teacher.

A sufism figure named Fathullah Gulen believes that the sufi order is the second step after the Shari'ah on the way to true nature. According to him sufism is different from the sufi order, if Sufism is the core of Islamic teachings while the sufi order is considered a product of history. ${ }^{24}$ This thought of Fathullah Gulen is sufism without sufi order. Gulen saw that sufism was the core of Islamic teachings, while the Shari'a was the wrapper. Creating harmony between sufism and jurisprudence is important for a Muslim. People who are concerned with outside aspects without paying attention to the aspects of the inside, it will lead to a dry understanding. According to Gulen sufism is the answer to modern needs that are experiencing drought. Gülen raised Sufism in the midst of modern society with necessary adjustments, which included sufism without following the rituals of one of the sufi order based on the Qur'an and also the Sunnah.

The element of life of sufism received considerable attention from the sources of Islamic teachings namely, the Qur'an and as-Sunnah. ${ }^{25}$ Shari'a sufism is also an Islamic esoteric dimension that must be maintained. ${ }^{26}$ Likewise with the essence which is the eye of the heart to see God, because the Shari'a is the spiritual path to nature. ${ }^{27}$ This style of thinking of Fathullah Gulen was heavily influenced by Nursi, because

\footnotetext{
${ }^{24}$ Akhmad Risqon Khamami, "Tasawuf Tanpa Tarekat: Pengalaman Turki dan Indonesia", 17.

${ }^{25}$ Rosihon Anwar, Ilmu Tasawuf (Bandung: CV. Pustaka Setia, 2000), 22

${ }^{26}$ Kautsar Azhari Noer, Tasawuf Perenial: Kearifan Kritis Kaum Sufi (Jakarta: PT Serambi Ilmu Semesta, 2003), 20.

${ }^{27}$ Syaikh Wan Ahmad Bin Muhammad. Z. Bin Mushthafa alFathani, Sufi dan Wali Allah (Bandung: Husaini, 1985), 3.
} 
Fathullah Gulen learned a lot from Nursi. Gulen was also very inspired by Nursi's spiritual life and his passion for serving the people. So Gulen applied Nursi's teachings in the hizmet principle.

Likewise with Nursi who explained that religiousness is a spiritual path that aims to recognize Allah SWT and achieve the belief of the faith and understand the Qur'an. Nursi described the potential of human hearts and feelings, as a seed for the subject of knowledge and truth, which also contained maps of thousands of worlds, just by repeating the designation the name of Allah Almighty or remembrance of Allah in the practice of the sufi order and trying to find faith faith will bear fruit and also grow the seed. Nursi also explained that the purpose of the sufi order is to recite Allah and muhasabah, because through both of them man will gain peace and strength in the world and also in the hereafter. Every problem and difficulty will surely disappear if we always feel together with God Almighty. Nursi stressed that sufis attest to the divine mission and the sufi order and the testimony of the Shari' $a,{ }^{28}$ they also illustrate the perfection of Islam.

For Nursi, the most beautiful and true religious life is the one that coincides with alSunnah and the most firm in obeying Islamic law, and the principle of virtue is sincerity, and also recognizing Allah SWT lovingly is the most important step. ${ }^{29}$ Nursi in one of his appreciation of the path of sufism stated that through a journey with heart and endless struggle against the temptations of satan and his personal desires, a sufismist will become a perfect human being. ${ }^{30}$

\footnotetext{
${ }^{28}$ Shari'a are regulations and laws that originate from Allah's revelation. The commands and prohibitions are clear and carried out for the welfare of all humans. Deepening the Shari'a as a rule and law of God is an obligation of Muslims, especially those relating to the worship of mahzah, namely worship that is directly related to Allah. Sayyid Abi Bakar Ibnu Muhammad Syatha, Misi Suci Para Sufi (Yogyakarta: Mitra Pustaka, 2000), 25. ${ }^{29}$ Syed Hadzrullathfi Syed Omar \& Nurul Aarifah Musa, "Tarekat Sufi Suatu Keperluan Zaman: Sorotan Pandangan Badiuzzaman Said Al-Nursi”, 414.

${ }^{30}$ Zaprulkhan, Perkembangan Kepribadian Secara Spiritual dalam Perspektif Badiuzzaman Said Nursi, Jurnal Farabi 12, no. 1 (2015): 96.
}

All paths of sufi order in Nursi's view are to achieve the truth of the Shari'a. The path taken by Nursi is different from other sufi order which prioritizes purification and glossing of the inner zahir of the practitioner, and also unlike the sufi order which tends to practice Allah's remembrance in the heart, and also differs from the group that reads general reading for purification of the heart. However, the path taken by Nursi is a spiritual path based on four steps taken from the Qur'an: first, from the word of God, then do not praise yourself that you are clean from $\sin ($ Q.S. al-Najm [53]: 32). Nursi explained that this step circumvented the proud and selfinducing salik. Second, the word of God says, "and do not be like those who have forgotten the commandments of Allah, then Allah made them forget good deeds to save themselves" (Q.S. alHashr [59]: 19). According to him, this step was perfected by carrying out every responsibility, willing with death and forgetting the rewards that would be obtained. Third, "if all the good favors of pleasure that you get then it is from God, and also if the disaster that befell you then it is from your own mistakes" (Q.S. al-Nisa' [4]: 79). Nursi stressed that the inauguration of this step was to acknowledge self-weaknesses and teach the practitioners to surrender and give thanks to Allah SWT. fourth, "each and every thing will perish through God" (Q.S. al-Qașaș [28]: 88) this step in Nursi's view educates practitioners to respect other creatures by always putting the witness of God in His creation. sanctification by tracing this path is to see that human form lies in the recognition that their destruction is certain. ${ }^{31}$

If there is a statement for a sufi order follower that a murshid is always protected from all mistakes is a sheer error. Their statement is clear without being based on religious knowledge. Like some of those who say that a sheikh or murshid knows everything his students do, even though a

\footnotetext{
${ }^{31}$ Syed Hadzrullathfi Syed Omar \& Nurul Aarifah Musa, "Tarekat Sufi Suatu Keperluan Zaman: Sorotan Pandangan Badiuzzaman Said Al-Nursi," 415.
} 
murshid is in bed. Others say that a murshid knows things that are unseen and knows everything that comes to the mind of each student. ${ }^{32}$ Things like this are something that is not possible, because in religious science such things are mere errors.

Joining one sufi order institution is not an obligation. Some of those who are obliged to enter the sufi order are statements without a basis. In essence, the commitment demanded from everyone Muslims are to be always cautious, adhere to the teachings of Islam, namely by doing everything that is required and away from everything that is prohibited. Meanwhile, the sufi order which contains recitation of remembrance with the promise or pledge of allegiance to a murshid to uphold the Islamic Shari'a its main goal is to increase the quality of piety. That is, joining the sufi order or not, the initial commitment ordered by Allah and His Messenger to every Muslim servant is to always maintain the values of piety and improve their quality in various circumstances and places. ${ }^{33}$

\section{b. Nursi Sufism without the Sufi Order}

The main purpose of Sufism is makrifatullah or knowing God. so the main step to enter the gate of sufism is to know who Allah is. Allah is the name of the essence of Wajib al-Wujūd, Allah is the creator of the universe, including humans, and to Him everything will be returned. So the first time, it is obligatory for us to believe or believe in God with out any doubt. ${ }^{34}$ Nursi's thoughts about Sufism are based on his understanding of the Qur'an and experience, both in reality, and because of his own spiritual journey. Nursi puts faith as the main foundation that must be improved in living life in the world, because according to Nursi faith is important in determining the safety of humanity.

\footnotetext{
${ }^{32}$ Kholilurrohman, Mengenal Tasawuf Rasulullah: Representasi Ajaran Al-Quran dan Sunnah (t.tp: t.p, t.t.), 308.

${ }^{33}$ Ibid., 311.

${ }^{34}$ Jamaluddin Kafie, Tasawuf Kontemporer, 2nd edition (Jakarta: Mutiara Al-Amien Prenduan, 2003), 1.
}

Nursi explained the explanation of sufism and sufi order as a way to get to know the essence of the faith and nature of the Qur'an through the spiritual path under the guidance of the Sunnah of the Prophet. This step starts from the heart so that it reaches a sense or zauq resembling the level of witnessing or shuhüd. ${ }^{35}$ This explanation opens Nursi's view that the goal of sufism and the tariqah is to achieve the essence of faith, and the Qur'an as a guide.

According to Nursi himself in his Risalah nur gave the definition of wahdah al-wujūd as a foundation of heart to the existence of Allah SWT which is obligatory al-wujūd or obligatory to exist and forget others. Every creature of an image or delusion that does not have the nature of being that is essential and is not worthy of being given the nature of existence in the context of the obligatory al-wujūd Allah Almighty. It is nothing more than the movement or reflection of the great attributes of Allah through asmā 'al-husnā. In the view of Nursi wahdah al-wujūd which embraces wahdah $a l$-shuhüd, that is, the unity of witnessing in it is a very important stopover of sufism. ${ }^{36}$

A person who follows the path of wahdah alwujūd if his soul is completely empty of material relations and everything that expresses itself to an object, then he will be able to break the curtain of causes and break free from that bond, then he experiences a level of witnessing of the heart that is sink the whole mind. According to Nursi sufism's experiences like this are the ones that may arrive at the station of al-wujūd which is experiential and not based on knowledge. Because he succeeded from wahdah al-shuhūd and not wahdah al-wujūd. When that witnessing

\footnotetext{
${ }^{35}$ This term can simply be interpreted as awareness or show to self-end that ends in a perpetrator and an eyewitness. Then specifically understanding the term by a Sufi al-Junaid in his theory of an actor, "everything that you see is the deeds and actions of Allah". thus, shuhūd is a complement to being. M. Abdul Mujie b, et al, Ensiklopedi Tasawuf Imam Al-Ghazali (Jakarta: PT. Mizan Publika, 2009), 470.

${ }^{36}$ Muhammad F aiz Khalid, "Wahdat Al-Wujud dan Kewalian Menurut Said Nursi Menerusi Karyanya Risale-I Nur,” Jurnal Hadhari 8, no. 2 (2016): 248.
} 
experience led him to fly toward perfection and special stages, he might reach the stage of denying the existence of this universe when all his attention was focused on the existence of the substance of Allah Almighty. But on the contrary if someone is in a state of drowning and all-material influences, the founding of wahdah al-wujūd will lead him to deny the existence of Allah Almighty, that is because his attention is fully focused on the existence of the universe and does not escape the boundaries of matter. Nursi also reminded that inviting and teaching ordinary people to understand wahdah al-wujūd at this time will bring immense harm, especially if this teaching changes hands from the special group to the lay class, or changes hands from scientists to the hands of ignorance, it will lose its essence. ${ }^{37}$

In Nursi view, a person's spirit can move and will continue to live by way of recitation to Allah and contemplation continuously. ${ }^{38}$ Activities like this will be able to eliminate depression, fear and a sense of alienation that is felt by every human soul. Remembrance in general is interpreted as an oral act while contemplation is an act of the mind, but basically the dhikr is not limited to being recited or spoken only by mouth but the heart should also recite its own practice of remembrance, that is by always feeling the greatness and power of Allah. That way we can

\footnotetext{
${ }^{37} \mathrm{First}$, that in general intends to deny the existence of nature and other creatures on the side of the existence of Allah SWT, but if it reaches the people who are negligent, especially those who are lost in the understanding of material things, then they will deny God and even glorify material things. Second, rejecting the lordship other than Allah so that this understanding will reject the existence other than Allah and also reject the manifestation of lust and anything other than that. But nowadays, materialism has gripped the Islamic world and lust has also gone mad especially for those who have begun to be willing to uplift and make their lust as God other than Allah SWT. Third, this understanding will give birth to seeds of thought and also images that are not worthy of the substance of Allah SWT, while the substance of God is clean and high and the most resilient of change, change, happiness and partiality. Then this kind of thinking will be the cause of the emergence of false teachings. Ibid., 251; also see Mulyadhi Kartanegara, Menyelami Lubuk Tasawuf, 36.

${ }^{38}$ Muhammad Faiz, "Konsep Tasawuf Said Nursi: Satu Penyegaran Wacana Sufisme Kontemporer," 2.
}

feel closeness to God. ${ }^{39}$

The rules and customs of the sufi order Nursi reminded that the practice of dhikr or wirid can produce a $d z a u q$ in the heart so that it becomes an opening way to a high and noble awareness that is to carry out all the commands of Allah and practice the Sunnah of the Prophet, not even vice versa as is the habit of some laypeople adherents which prioritizes the dhikr and also the wirid of the sufi order compared to the practices of $f a r \underline{d} u$ and sunnah.

Nursi argued that sufism and sufi order are only an intermediary and not a destination in the religious journey. Therefore Nursi reminded again that the implementation of a far $\underline{d} u$ practice on the basis of obedience to the Shari' a of God was greater and also more important. Things like this cannot be equated with the practice of remembrance and practice of sufi order let alone believe that the practice of sufi order is more important than religious orders, namely Shari'a. ${ }^{40}$

The colors of sufi Nursi's thinking could have been shaped by the environment and the sufi order Naqsabandy its environment tradition. When viewed from the historical context Nursi lived in a period of intense debate which tended to judge the sufi order as a source of Islamic decline. Furthermore, because Nursi grew up in an unfavorable political environment where Kemal Attaruk banned sufi order and zâwîyah. Nursi also grew up in an era where when the Ottoman Sultanate was aggressively adopting science. With the renewal process in the Sultanate, intellectuals who follow the philosophy of materialism strictly forbid the teachings of Islam. They challenge the relationship of religious faith. Nursi saw the philosophy of materialism as a serious threat to the existence of faith. Whereas this attack of materialism can only be broken by a rational religious approach, not just if it tastes like a sufi

\footnotetext{
${ }^{39}$ Ilyas Fahmi Ramadlani, "Perjuangan Badiuzzaman Said Nursi dalam Membendung Arus Sekularisasi di Turki," Nalar: Jurnal Peradaban dan Pemikiran Islam 3, no. 1 (2019): 45. ${ }^{40}$ Ibid.
} 
order. This is one of the causes of Nursi thoughts.

Nursi left the sufi order to be free from repression by the Kemalist regime. The founder of the Narcu movement and its followers experienced oppression. For the rulers of the Turkish republic at that time, the sufi order and the Narcu movement were considered a threat to the continuation of secular government. The sufi order are oppressed because sufi order are considered as forbidden intuition, while the Narcu movement is oppressed on the charge of forming sufi order. Nursi also answered the group who did not have a spiritual teacher in sufism, so the teacher was a devil, Nursi stressed that the teacher who could be used was to make Nur's treatise book a teacher and also a spiritual guide. ${ }^{41}$

The decline of the Ottoman Empire was a bad mirror of the condition of Muslim countries, because Islamic religious education in schools was abolished, Arabic letters were changed to Latin letters. The Ottoman Turkish dynasty was declared a secular state and horrific courts throughout the country were established to impose guilty verdicts on the scholars, and the translation of the Qur'an was replaced with Turkish. This makes Nursi want to rebuild the religion of Islam which will make changes in the Turkish state, by rebuilding the faith of someone who is based on Islamic law.

The decline of the Ottoman Empire was a bad mirror of the condition of Muslim countries, because Islamic religious education in schools was abolished, Arabic letters were changed to Latin letters. The Ottoman Turkish dynasty was declared a secular state and horrific courts throughout the country were established to impose guilty verdicts on the scholars, and the translation of the Qur'an was replaced with Turkish. This makes Nursi want to rebuild the religion of Islam which will make changes in the Turkish state, by rebuilding the faith of someone who is based on Islamic law to follow the procedures as taught by

${ }^{41}$ Tabrani, "Perubahan Ideologi Keislaman Turki," Jurnal Edukasi 2, no. 2 (2016). the sufi order of the sufi orders. Now is the time to save faith." ${ }^{42}$

The color of sufism in Nursi's thoughts was also heavily influenced by various sufi figures such as Shaykh 'Abd al-Qodir al-Jailani, Jalaludin Rumi, Baha al-Din al-Naqsabandiyah, Ahmad Sirhindi and Khalid al-Baghdadi, because Nursi quoted the opinions of the figures in these writings. Even when Nursi experienced an inner shock before the change from the old phase to the new, Nursi found a cure for medicine from the book 'Abd al-Qodir al-Jailani and Ahmad Sirhindi.

Based on the research conducted by the author above, it can be that actually Nursi did not leave sufism at all. However, Nursi did not take the sufi order as an institution. Nursi only took his spiritual value. But even though he did not subscribe to one of the sufi order, Nursi continued to appreciate the teachings of sufism as long as he was still in the corridor of the Qur'an and the Sunnah of the Prophet. upholding the Shari'a, prioritizing the Qur'an and making the Prophet a role to emulate. This makes a difference of opinion from some scholars, because for someone adherents of an institute of sufi order will surely say that a murshid or teacher is very important in guiding students toward the level to get to God Almighty. In contrast to scholars who think that only by performing sufism without following the institution of the sufi order one can draw closer to Allah. This explanation will be further clarified in the discussion of pros and cons as well as against the thoughts of Nursi.

Nursi's ideas and views also refreshed the discourse of sufism and the sufi order as important elements of the concept of education in today's modern era. Where the challenges of the clergy (ulama) in particular are getting bigger in the face of an era that is completely materialistic, hedonist, and even atheist. Nursi contributed to

\footnotetext{
${ }^{42}$ Irmayanti, "Badiuzzaman Said Nursi (Studi Tentang Peranannya Terhadap Perkembangan Islam Masa Pemerintahan Mustafa Kemal Attaturk)," Skripsi Fakultas Adab dan Humaniora UIN Alauddin Makassar, 2017. 46
} 
his moderate sufism concept, which was easy to digest and followed by ordinary people as an important element in the building of education. According to him, a clear mission to save the faith of the people of today is more important than the practice of the sufism order which is exclusive and carries the risk of being perverted and the denial of faith. The essence of achieving faith that radiates spirituality and morality as the principle of education in the Nursi principle is like eating rice or staple food,

This is because the reality of today's Muslim world community requires more basic spiritual intake than additional food (vitamins) for the soul. Nursi tried to restore the contemporary Muslim paradigm to refer directly to the basic values of the Qur'an and the Sunnah of the Prophet Muhammad in guiding the journey to find the essence of God. Thus, the urgency and relevance of combining the three main elements of education in today's era cannot be negotiated, scientific experts must study religious knowledge, as well as scholars must also develop modern science and technology with the dress of Qur'anic morals. In this way, education becomes a determining aspect of the advancement of human civilization.

\section{c. Ulama Who Agree With The Thought of Nursi About Sufism Without Sufi Order}

The spiritual path that is commonly referred to as sufism is a legacy of Islam, or irfan which is an Islamic tradition since centuries. In the sufism tradition spiritual pathers can be called people who take the path of Allah. In Egypt there used to be a writer of sufism and maybe even a sufi who did not like the sufi order. Abdul Halim Mahmud who was born in 1910, he practiced sufism but did not follow any tarekat, he even had time to criticize the flow which he considered worshiping their teacher which is contrary to Islamic teachings. In the teachings of sufism a lot of people who walk the path of sufism without following any sufi order, because the sufi order only appeared at the final development in history.
But there are also Muslims who follow the path of the sufi order, that is, they study sufism through sufi order schools. That is $\mathrm{OK}$, as is the case for people who want to join Muhammadiyah or NU, that's fine. So the sufi order is the same as an organization only without permission from the Ministry of Home Affairs. ${ }^{43}$

Sufism figure Fathullah Gulen considers thats is not just a matter of spirituality, but also a social problem. Sufism must reflect in community life. This social sufism requires a sufism practitioner who has achieved spiritual enjoyment to maintain social order and world peace. After achieving spiritual pleasure and returning to society, the next task is to maintain awareness of God's existence in the community. Because spiritual awareness is tested when one is in society. From this it is clearly seen that sufism Gulen does not separate the afterlife from the life of the world. ${ }^{44}$

The piety of sufism for Gulen must be in the form of community service. The peak of sufism does not only stop on itself, but the manifestation in people's lives. According to him sufism is a cure for humanitarian problems in the contemporary era. The loss of humanism with this much propaganda in hatred and hostility is a fundamental problem. The only way to overcome this humanitarian problem, according to Gulen, is by reviving love and tolerance. Love can come back by presenting sufism. In addition, it is only with sufism that spirituality can be resurrected. ${ }^{45}$

Hamka also argues in his early work modern sufism, in the view of Hamka sufism is a process of cleansing the heart from a variety of liver diseases and despicable traits, such as greedy, arrogant, envious, jealous, and others to decorate the heart with a variety of noble morals . Through various kinds of mental training, at the ideal point Hamka recognizes that people who live it will

\footnotetext{
${ }^{43}$ Liga Suryadana, Sosiologi Peristiwa: Kajian Keperistiwaan dalam Paradigma Intergratif-Transformatif Menuju Wisata Spiritual (Bandung: Humaniora, 2013), 185.

${ }^{44}$ Akhmad Risqon Khamami, "Tasawuf Tanpa Tarekat: Pengalaman Turki dan Indonesia," 19.

${ }^{45}$ Ibid.
} 
open the veil that blocks themselves with God. Hamka also built sufism based on the Qur'an and Sunnah. In addition, Hamka did not formulate a system or standard rules as conceptualized by most sufi teachers based on agreement. Hamka's sufism discourse was built in such a way and simple that it was accessed by all groups, not just special groups. Further, Hamka does not say himself as a spiritual teacher or a murshid where anyone who wants to practice the sufism discourse that Hamka gives can be practiced without having a sacred bond between himself and his students. With this Hamka can be classified as sufism figures without sufi order. ${ }^{46}$ This sufism is the same as the modern sufism Nursi.

Indirectly, scholars such as Abdul Halim Mahmud, Fathullah Gulen and Hamka also agree with Nursi's thought that a person who is sufi if not following the sufi order or has a murshid is not a problem, but even so it does not mean that the ulama oppose the practices. existing sufi order. Because the sufi order is basically also a way to get closer to Allah, by way of remembrance and glorifying the names of Allah. it's just that the scholars do not want to have a bond or be bound by an institution, which most of the followers of the sufi order must be included in an institution, which in this case must be bound by a certain teacher or murshid.

Meanwhile, according to Nursi himself, when someone wants to draw closer to Allah or to have an agreement, it is not necessary to have an association between a murshid and a student, by practicing Allah's commands like always performing the obligatory prayers or sunnah and also always making remembrance of Allah is the same as engaging/sufi order.

\section{d. Ulama who Contradict the Thought of Nursi About Sufism Without Sufi Order}

Luqman Hakim caretaker of Pondok Pesantren Ma'had Aly Raudhatul from Caringin Bogor, known as an expert and perpetrator of the

\footnotetext{
${ }^{46}$ Zaprulkhan, Ilmu Tasawuf Sebuah Kajian Tematik, 281.
}

sufi order, that a person who suffers but does not compete is equal to zero. Practice their knowledge, because according to him a person who is fighting automatically he will be given guidance in sufism, because a follower of that congregation has a teacher or musyid who will guide him. ${ }^{47}$ Religiously, the sufi order becomes a vehicle for inculcating religious values in the midst of society. The sufi order here can contribute ethically and spiritually in the midst of national discourse which is characterized by various social, political, and economic problems. While institutionally, the sufi order becomes a vehicle for the articulation of social interests. Referring to the historical experience of sufi order in the socio-political dynamics in various countries, sufi order can become a network for religious social movements. ${ }^{48}$

Sufi teacher Seyyed Hossein Nasr explained that a spiritual teacher who is usually called a mursid is very necessary for a student, because a mursid always guides students in conducting spiritual teachings. ${ }^{49}$ With this it can be that a person who embraces the spiritual path such as sufism accompanied by a sufi order institution which has a murshid, is a must for a sufi order institution because this is a way to take the true nature towards the path to Allah.

Most of the sufi order scholars do say that people who follow the teachings of the sufi order are certainly sufism. Because the way to get close to God must be done in three ways, namely, the Shari' a which is a word, while the sufi order is an action and also the nature which is the condition of the mind. If the person has reached these three stages, he will feel close to Allah. So in this case there are scholars who disagree with the idea of sufism without sufi order. Indeed, in the opinion of the scholars who follow the path of the sufi

\footnotetext{
${ }^{47} \mathrm{http}$ //www.nu.or.id/post/read/38418/tasawuf-tanpa-thariqahsama-dengan-nol, accessed on 24 August 2018, at 9:28.

${ }^{48}$ Muhsin Jamil, Tarekat dan Dinamika Sosial Politik (Tafsir Sosial Sufi Nusantara) (Yogyakarta: Pustaka Pelajar, 2005), 43.

${ }^{49}$ Zaprulkhan, Ilmu Tasawuf Sebuah Kajian Tematik, 73.
} 
order, someone who is sufism should indeed be accompanied by the teachings of the sufi order. Like KH Lukman Hakim and Seyyed Hossein Nasr above who that people who are sufism but do not compete are just as empty. Because according to him, someone who wants to have or understand spiritual knowledge must be guided by a student who really understands his essence. Because in the guidance process a student can understand the teachings about the nature of truth and faith for someone who wants to draw closer to God.

\section{Conclusion}

Based on research and analysis that has been done about the concept of sufism without sufi order according to thought Badiuzzaman Siad Nursi, With wahdah al-wujūd who recognizes and believes in the existence of Allah. So that it can just make someone go on the path of being active in carrying out worship to God and obeying it continuously without committing disobedience. Even so interesting, some people consider themselves to be sufism but do not follow one of the teachings of the sufi order. Sufism and sufi order are a way to draw closer to Allah. However, Nursi did not follow the teachings of the sufi order. Starting from that Nursi argued that sufism is a way to recognize the nature of the faith and nature of the Qur'an through the spiritual path under the guidance of the Prophet's sunnah. The definition of sufism explained by Nursi emphasizes the object and target of sufism itself, namely the attainment of the nature of the faith and the revealed nature of the Qur'an of the Qur'an as the basis and guide of human life. Besides that, it can also be understood that the sunnah of the Prophet(s) is a guideline that guides a person's sufi journey to reach a level of closeness to Allah, known in the environment of sufism with the term ma'rifatullah.

Indeed Nursi did not leave sufism at all. However, he did not take the tarekat as an institution. It only takes its spiritual value. Even though he does not adhere to one of the tarekat, ursi still appreciates the teachings of sufism as long as it is still within the corridor of the alQur'an and the Sunnah of the Prophet. As a figure who upholds sharî'ah, prioritizes the Qur'an, and makes the Prophet a role model, Nursi can be included in the category of followers of the "Muhammadiyah sufi Order". As mentioned earlier, following the "Muhammadiyah Sufi Order" can be said to be sufism without sufi order.

Ulama who are pro towards the thought of sufism without sufi order Nursi namely Abdul Halim Mahmud, Fathullah Gulen, and also Hamka agree with Said Nursi's thought, namely a person who undertakes sufism if he does not follow the sufi order or has a murshid is not a problem, but even so, it does not mean that the scholars are against the existing practices of the sufi order. Tarekat is also a way to get closer to Allah, through dhikr and glorifying the name of Allah. It's just that the ulama do not want to be bound or bound by an institution, where most of the tarekat followers have to enter into an institution, which in this case must be tied to a certain teacher or murshid.

Meanwhile, the Ulama who are contradicting sufism thought without sufi order Nursi's congregation, namely KH Lukman Hakim and Seyyed Hossein Nasr, believe that people who practice sufism but do not have a strong opinion are just empty. Because according to him, someone who wants to have or understand spiritual knowledge must be guided by a murshid who understands its essence. Because in the guidance process a student can understand teachings about the nature of truth and faith for someone who wants to get closer to Allah.

\section{References}

Ahmad, Syaikh Wan Bin Muhammad. Z. Bin Mushthafa al-Fathan. Sufi dan Wali Allah. Bandung: Husaini, 1985.

al-Kumayi, Sulaiman. "Konsep Sufisme 'Shakhs-I 
Manevi dan Hizmet Muhammad Fathullah Gulen.” Jurnal Studi Keislaman 17, no. 2 (2013).

Amin, Samsul Munir. Ilmu Tasawuf. Jakarta: AMZAH, 2012.

an-Naisabury, Abdul Qosim al-Qusyairy. Risalah Qusyairiyah Induk Ilmu Tasawuf. 7th edition. Surabaya: Risalah Gusti, 2014.

Anwar, Rosihon. Ilmu Tasawuf. Bandung: CV. Pustaka Setia, 2000.

Bagir, Haidar. Buku Saku Tasawuf Positif. Bandung: Mizan Pustaka, 2005.

Dahlan, Zaini. Quran Karim dan Terjemah Artinya. Yogyakarta: UII Press, 1999.

Daudy, Ahmad. Kuliah Ilmu Tasawuf. Jakarta: Bulan Bintang, 1998.

Faiz, Muhammad. "Konsep Tasawuf Said Nursi: Satu Penyegaran Wacana Sufisme Kontemporer." Paper presented at the AlZehra Writing Competition by Dershane Egypt, in 2015.

"Risalah Nur dan Gerakan Tarekat di Turki: Peran Said Pada Awal Pemerintahan Republik." Al-A 'raf XIV, no. 1 (2017).

Gitosaroso, Muh. Syari'at dan Tarekat dalam Persepektif Jama'ah (Studi atas Jama'ah Tarekat Haq Naqsabandiyah di Kota Pontianak). Pontianak: IAIN Pontianak Press, 2017.

Gulen, M. Fethullah. Key Concepts In Practice Of Sufism Emrald Hills Of The Hert. Turkey: The Light, 2004.

http://www.nu.or.id/post/read/38418/tasawuftanpa-thariqah-sama-dengan-nol, accessed on 24 August 2018, at 9:28.

http://www.sarjanaku.com/2011/11/persontarekat-and sejarah.html, accessed on August 18, 2019, at 12:19

Irmayanti. "Badiuzzaman Said Nursi (Studi Tentang Perananny Terhadap Perkembangan Islam Masa Pemerintahan Mustafa Kemal Attaturk)." Skripsi Fakultas Adab dan Humaniora UIN Alauddin Makassar, 2017.
Isa, Syaikh 'Abdul Qodir. Hakekat Tasawuf. Jakarta: Qisthi Press, 2005.

Jailani, Syaikh Abdul Qadir. Fiqih Tasawuf. Bandung: Pustaka Hidayah, 2001.

Jamil, Muhsin. Tarekat dan Dinamika Sosial Politik (Tafsir Sosial Sufi Nusantara). Yogyakarta: Pustaka Pelajar, 2005.

Kabbani, Syekh Muhammad Hisyam. Tasawuf dan Ihsan (Antivirus Kebatilan dan Kezaliman). Jakarta: Serambi Ilmu Semesta, 2007.

Kafie, Jamaluddin, Tasawuf Kontemporer. 2nd edition. Jakarta: Mutiara Al-Amien Prenduan, 2003.

Tasawuf Kontemporer. Jakarta: Republika, 2003.

Kartanegara, Mulyadhi. Menyelami Lubuk Tasawuf. Jakarta: Erlangga, 2006.

Khalid, Muhammad Faiz, "Wahdat Al-Wujud dan Kewalian Menurut Said Nursi Menerusi Karyanya Risale-I Nur." Jurnal Hadhari 8, no. 2 (2016).

Khamami, Akhmad Risqon. "Tasawuf Tanpa Tarekat: Pengalaman Turki dan Indonesia." Teosofi: Jurnal Tasawuf dan Pemikiran Islam 6, no.1 (2016).

-------. "Kontribusi Gerakan Nurcu dalam Kebangkitan Islam di Turki. Islamica: Jurnal Studi Keislaman 10, no. 1 (2015).

Kholilurrohman. Mengenal Tasawuf Rasulullah: Representasi Ajaran Al-Quran dan Sunnah. t.tp: t.p, t.t.

Masyhuri, Aziz. Ensiklopedi 22 Aliran Tarekat dalam Tasawuf. Surabaya: Imtiyaz, 2011.

Mujieb, M. Abdul, et. al. Ensiklopedi Tasawuf Imam Al-Ghazali. Jakarta: PT Mizan Publika, 2009.

Noer, Kautsar Azhari. Tasawuf Perenial: Kearifan Kritis Kaum Sufi. Jakarta: PT. Serambi Ilmu Semesta, 2003.

Nur, Edy Yusuf. Menggali Tasawuf Yang Haqiqi. Yogyakarta: SUKA-Pres UIN Sunan Kalijaga, 2014.

Nursi, Badiuzzaman Said. Al-Maktûbât. 
Translated by Fauzi Faisal Bahreisy. 1st edition. Banten: Risalah Nur Press, 2017. Khutbah Syamiyah (Manifesto Kebangkitan Umat). Jakarta: Risalah Nur Press, 2014. -------. Menjawab Yang Tak Terjawab Menjelaskan Yang Tak Terjelaskan. Translated by Sugeng Hariyanto. Jakarta: PT. Raja Grafindo Persada, 2003.

Omar, Syed Hadzrullathfi Syed \& Nurul Aarifah Musa. "Tarekat Sufi Suatu Keperluan

Zaman: Sorotan Pandangan Badiuzzaman Said Al-Nursi". Proceedings of ICIC 2015 - International Conference on Empowering Islamic Civilization in the 21st Century. Malaysia: Terengganu, 6-7 September 2015.

Ramadlani, Ilyas Fahmi. "Perjuangan Badiuzzaman

Said Nursi dalam Membendung Arus Sekularisasi di Turki." Nalar: Jurnal Peradaban dan Pemikiran Islam 3, no. 1 (2019).

Sakhok, Jazilus and Siswoyo Aris Munandar. "The Sufi Order and Phianthropy: A Case Study of Philantrophical Activitism of The Naqsyabandiyah Al-Haqqani Sufi Order in Indonesia." Teosofia: Indonesia Journal of Islamic Mysticism 8, no. 1 (2019).

Salih, Ihsan Kasim. Said Nursi: Pemikiran dan Sufi Besar Abad 20 Membebaskan Agama dari Dogmatisme \& Sekularisme. Jakarta: PT Raja Grafindo Persada, 2003.

Shihab, M. Quraish. Menabur Pesan Ilahi (Al-Qur'an dan Dinamika Kehidupan
Masyarakat). Jakarta: Lentera Hati, 2006. Sholikhin, Muhammad. Hadirkan Allah di Hatimu. Solo: Tiga Serangkai, 2008.

Suhayib. "Pemikiran Said Nursi dalam Pemberdayaan Politik (al-Tamkin alSiyasi) Masyarakat Muslim Turki (Studi atas Kitab al-Matsnawi an-Nuri)." AnNida'38, no.1 (2013).

Suryadana, Liga. Sosiologi Peristiwa: Kajian Keperistiwaan dalam Paradigma Intergratif-TransformatifMenuju Wisata Spiritual. Bandung: Humaniora, 2013.

Syatha, Sayyid Abi Bakar Ibnu Muhammad. Misi Suci Para Sufi. Yogyakarta: Mitra Pustaka, 2000.

Tabrani. "Perubahan Ideologi Keislaman Turki." Jurnal Edukasi 2, no. 2 (2016).

Vahide, Sukran. Biografi Intelektual Bediuzzaman Said Nursi: Trasformasi Dinasti Usmani Menjadi Republik Turki. Jakarta: Fajar Interpratama Offset, 2007.

Yulianti, Angelia, "Proses Integrasi Pemikiran Anti Sekularisme dengan Pendidikan Agama Islam Menurut Badiuzzaman Said Nursi." Thesis submitted to the Faculty of Tarbiyah and Teacher Training UIN Sunan Kalijaga Yogyakarta, 2014.

Zaprulkhan, Ilmu Tasawuf: Sebuah Kajian Tematik. Jakarta: Rajawali Pers, 2016. . "Perkembangan Kepribadian Secara Spiritual dalam Perspektif Badiuzzaman Said Nursi." Jurnal Farabi 12, no. 1 (2015). 